\title{
Effects of Information and Communication Technology Adoption on Msmes in the Retail Sector Marketing Performance in Cibaduyut Area, Bandung City
}

\author{
Fajar Sukma Dewanta \\ Department of Business Administration Padjadjaran University, \\ Bandung, Indonesia \\ Mohammad Benny Alexandri \\ Department of Business Administration Padjadjaran University, \\ Bandung, Indonesia \\ Nenden Kostini \\ Department of Business Administration Padjadjaran University, \\ Bandung, Indonesia
}

\begin{abstract}
Micro, small and medium enterprises (MSMEs) have become priority for economic development as an effort to increase the competitiveness of MSMEs. Moreover, MSMEs have the potential and also become the driving force of the Indonesian economic development. Cibaduyut area, which is the main center of the textile industry and processing in Bandung City. However, MSMEs in this area have faced great pressure since the enactment of the ASEAN-China Free Trade Area (ACFTA) in 2010. There have been efforts made by businessmen, especially the retail sector in this area to increase the company competition by adopting Information and Communication Technology (ICT). This study aims to find out how the ICT effects on company performance in the retail sector MSMEs in Cibaduyut area, especially towards marketing performance. Respondents in this study were sampled using proportionate stratified random sampling to determine the number of samples based on the size of the business. The analysis technique used is multiple regression analysis using the SPSS 22.0 application. The results showed that there are significant effects between Information Technology, Communication Technology and also between Information Technology and Communication Technology on MSMEs Marketing Performance in the retail sector in Cibaduyut, Bandung City.
\end{abstract}

Keywords: information technology, communication technology, marketing performance, msmes

\section{INTRODUCTION}

Micro, small and medium enterprises (MSMEs) have become priority of economic development which is seen as an effort to increase the competitiveness of MSMEs and accelerate economic recovery to overcome poverty and unemployment in Indonesia. MSMEs also have the potential to become the driving force of the economy, besides growing large and engaged in every sector of the economy, MSMEs also able to absorb large numbers of workers, even less skilled ones. According to the Ministry of Industry in 2017, MSMEs contributed to the Gross Domestic Product (GDP) which continued to increase to $60.34 \%$ in the last five years and the absorption of labor from this sector continued to grow to $97.84 \%$. The contributions given by MSMEs have made this sector as a strategic role in fighting poverty and unemployment. 
Furthermore, the contribution given by MSMEs in Cibaduyut area, which is the main center of the textile industry and processing in Bandung City. However, MSMEs in the Cibaduyut must face great pressure from China and other Southeast Asian countries. MSMEs in Bandung City especially in the fashion and footwear sector, already faced such pressure since the enactment of the ASEAN-China Free Trade Area (ACFTA) back in 2010 and the existence of the ASEAN free trade agreement or the ASEAN Economic Community (MEA) in 2015 which puts pressure on competitiveness local industry. This has resulted the development activities of the footwear industry in Cibaduyut generally have decreased since the trade agreement was implemented.

One reason is that industries from China, in particular, have produced goods with advanced technology with low cost so that they can produce large quantities of goods at lower prices. Industries in China have used adequate technology to market their products so that they can effectively market to various countries. Compared to Indonesia, the awareness about the importance of technology in MSMEs relatively low. The AMI Partners research institute revealed the fact that only $20 \%$ of MSMEs in Indonesia have computers to support their business activities (Wahid, 2007). The adoption level of Information and Communication Technology (ICT) in MSMEs in Indonesia is also relatively low, which is at level 1 out of 5, namely the use of ICTs in MSMEs in Indonesia only in internal-oriented functional integration of companies (Wahid, 2007). Most MSMEs in Indonesia run their business using traditional methods including production and marketing. Also, the level of utilization of Information Technology in the MSMEs sector is still low (Roosdhani et al., 2012).

Information Technology itself is a set of tools to help facilitate the implementation of tasks through information processes (Haag and Keen, 1996: 29). According to Abdul Kadir and Terra Ch Triwahyuni (2003: 2) Information Technology is a set of tools that help do work with information and perform tasks related to information processing. Trimi (2008: 2) stated that Information Technology plays an important role in increasing company agility, especially for micro, small and medium enterprises. This statement is supported from a number of literatures regarding the effects of Information Technology on MSMEs, namely better cost efficiency and marketing (Shiels et al., 2003; Akpan-Obong, 2007), and superior procurement systems and better distribution methods (Collins et al., 2010).

Furthermore, Sutarman (2009: 17) stated the purpose of Information Technology was to solve problems; to open creativity; and to increase effectiveness and efficiency in doing work. Sutarman (2009: 18) also stated that 6 (six) functions of Information Technology are as follows:

1. Capture;

2. Processing;

3. Produce;

4. Storage;

5. Retrival;

6. Transmission.

Rogers (1986: 2) stated that communication technology is a hardware device in an organizational structure that contains social values, which allows each individual to collect, process and exchange information with other individuals. The presence of communication technology cannot be separated from the culture that grows and develops in the midst of human life. Therefore, Mc Comber (in Abrar 2003: 7) stated, the linkages between Communication Technology and culture can be seen from three points of view, as follow:

1. Communication Technology as a determinant factor in society. That means that technology can create social change and change people's lives, for example being more 
egalitarian. In this case, technology is seen as a stand-alone factor and can create social change.

2. Communication Technology as a product of industrialization. That means that technology was created in large quantities in bulk, even expecting a multiple advantage over the product. Technology will also eventually form a technological society that prioritizes cultural professionalism which includes the principles of expertise, authority, autonomy and integrity.

3. Communication technology as a renewable element. That means that the difficulty to predict how much social power exists in society and it is difficult to estimate how much social power can affects the creation of Communication Technology.

Furthermore, marketing performance is a construct commonly used to measure the impact of implementing a corporate strategy (Ferdinand, 2000: 115). However, the problem of performance measurement is a classic problem and debate because as a construct, Marketing Performance is multidimensional in that it contains various objectives and types of organizations. Therefore performance should be measured using a variety of measurement criteria or multiple measurements, if using measurements with a single criteria or single measurement then it will not be able to provide a comprehensive understanding of how the performance of an actual company. (Prasetya, 2002: 227). By following the approach used by Homburg (2007: 21), marketing performance is defined as the effectiveness and efficiency of marketing activities of an organization related to the goal of reaching the market, namely income, growth, and market share.

Information Technology is the progress of devices that can help the decision making process at work. Progress in Information Technology can affect competitive strategies and operational effectiveness. Information Technology Effectiveness focuses on the process that will be achieved by the company. The application of Information Technology management is very important, to increase the complexity of the task of management, to follow the effects of globalization, respond to time more quickly, and survive due to pressure from business competition. There is no business or strategy among companies that do not use Information Technology.

The use of ICTs gives MSMEs a wide opportunity to participate in regional and international markets and reach the global customer base. According to Trimi (2008: 2), in MSMEs, ICT plays an important role in increasing company agility. The application of ICT offers many benefits in various fields of intra and inter-company business processes and transactions (Apulu and Latham, 2011). ICT is also expected to give MSMEs a competitive advantage in increasing integration between supply chain trading partners (Bhagwat and Sharma, 2007: 46).

However, in the retail sector MSMEs in Cibaduyut area, ICT adoption in general has grown quite significantly. The owner of the company has realized the importance of using technology for company performance in order to be able to keep up at the companies competition. Based on the results of research by the author using a model proposed by Knoll and Stroeken (2001), the level of ICT adoption in the retail sector MSMEs in Cibaduyut, Bandung City, is at level 3, namely the adoption of external-oriented multifunctional ICTs. From the findings above, it is known that the level of ICT adoption in the retail sector in the Cibaduyut Region is higher than the average level of ICT adoption in Indonesia. The retail sector in the Cibaduyut Region has been able to market its products to 27 countries, such as China, Denmark, Argentina, France, Mexico, Thailand and Vietnam with the largest exports to the United States. Therefore, in this study, the author will discuss how the ICT adoption affects on the Marketing Performance of MSMEs in the retail sector in Cibaduyut, Bandung City. 


\section{Hypothesis}

In this research, the following hypothesis formulated as follows:

H1: There is a significant effects between Information Technology on MSMEs in the retail sector marketing performance in Cibaduyut Area, Bandung City.

H2: There is a significant effects between Communication Technology on MSMEs in the retail sector marketing performance in Cibaduyut Area, Bandung City.

H3: There is a simultaneous effects between Information Technology and Communication Technology on MSMEs in the retail sector marketing performance in Cibaduyut Area, Bandung City.

\section{RESEARCH METHODS}

The method applied in this research is descriptive verification method. Descriptive method is used to describe problems related to effects of ICT on MSMEs, while verification analysis is an analysis and verification model to find out the truth of the proposed hypothesis. The overall population of MSMEs in the retail sector in Cibaduyut is 165. By using the Slovin formula, 62 samples were obtained. Moreover, this research also use proportionate stratified random sampling technique to determine the number of samples based on company size. According to the samples obtained, there are medium-scale businesses ( 9 samples), small-scale businesses (22 samples) and micro-scale businesses (31 samples). The analysis technique applied is multiple linear regression using the SPSS 22.0 application.

\section{RESEARCH RESULTS AND DISCUSSION \\ Effects of Information Technology and Communication Technology on Marketing Performance}

The following are the results of the analysis of the influence of Information and Communication Technology on MSME Marketing Performance in the Retail Sector in Cibaduyut, Bandung City. The variables in this study are Information Technology (X1), Communication Technology (X2) and Marketing Performance (Y).

Table 1.1

Effect of Information Technology on Marketing Performance

Coefficients a

\begin{tabular}{|c|c|c|c|c|c|c|}
\hline \multirow{2}{*}{\multicolumn{2}{|c|}{ Model }} & \multicolumn{2}{|c|}{$\begin{array}{c}\text { Unstandardized } \\
\text { Coefficients }\end{array}$} & \multirow{2}{*}{$\begin{array}{c}\text { Standardized } \\
\text { Coefficients }\end{array}$} & \multirow[b]{2}{*}{$\mathrm{t}$} & \multirow[b]{2}{*}{ Sig. } \\
\hline & & $\mathrm{B}$ & Std. Error & & & \\
\hline \multirow[t]{3}{*}{1} & (Constant) & -.406 & .212 & & -1.917 & .060 \\
\hline & Information Technology & .583 & .080 & .555 & 7.295 & .000 \\
\hline & Communication Technology & .617 & .109 & .430 & 5.650 & .000 \\
\hline
\end{tabular}

a. Dependent Variable: Kinerja Pemasaran

Source: Data Processing Results, 2018

Based on the table above, it can be seen that the direction of the relationship between Information Technology and Marketing Performance is positive, there is written 0.583 meaning that when there is an increase in Information Technology it will improve Marketing Performance. Based on the provisions stated earlier, where t-count is 7,295 and free degrees (n-k-1) or 62-2-1 = 59 are obtained $t$ numbers 2,001, so t-count $>\mathrm{t}$-table. This means that $\mathrm{H} 0$ is rejected and Ha is accepted, so there is a significant effect between Information Technology on Marketing Performance. Thus the hypothesis which states that there is an effect between Information Technology on Marketing Performance is acceptable. 
Table 1.2

Effect of Communication Technology on Marketing Performance

Coefficients

\begin{tabular}{|c|c|c|c|c|c|}
\hline \multirow{2}{*}{ MODEL } & \multicolumn{2}{|c|}{ Unstandardized Coefficients } & \multirow{2}{*}{$\begin{array}{c}\text { Standardized } \\
\text { Coefficients } \\
\text { Beta }\end{array}$} & \multirow{2}{*}{$\mathrm{t}$} & \multirow{2}{*}{ Sig. } \\
\hline & $\mathrm{B}$ & Std. Error & & & \\
\hline 1. (Constant) & -.406 & .212 & & -1.917 & .060 \\
\hline $\begin{array}{l}\text { Information } \\
\text { Technology }\end{array}$ & .583 & .080 & .555 & 7.295 & .000 \\
\hline $\begin{array}{l}\text { Communication } \\
\text { Technology }\end{array}$ & .617 & .109 & .430 & 5.650 & .000 \\
\hline
\end{tabular}

a. Dependent Variable: Marketing Performance

Source: Data Processing Results, 2018

Based on the table above, it can be seen that the direction of the relationship between Communication Technology and Marketing Performance is positive, as shown, 0.617 which means that when there is an increase in Communication Technology it will improve Marketing Performance. Based on the provisions stated earlier, where t-count is 5.650 and free degrees (n-k-1) or $62-2-1=59$, the $t$ table is 2.001, so t-count $>t$-table. This means that $H 02$ is rejected and Ha2 is accepted, so there is a significant effect between Communication Technology on Marketing Performance. Thus the hypothesis which states that there is an effect of Communication Technology on Marketing Performance is acceptable.

\section{Effects of Information and Communication Technology on Marketing Performance}

Table 2.

Effect of Information and Communication Technology on Marketing Performance ANOVA $^{\mathrm{b}}$

\begin{tabular}{|l|c|c|c|c|c|}
\hline MODEL & $\begin{array}{c}\text { Sum of } \\
\text { Squares }\end{array}$ & $\mathrm{df}$ & Mean Square & $\mathrm{F}$ & Sig. \\
\hline 1. Regression & 22.299 & 2 & 11.150 & 113.298 & $.000^{\mathrm{a}}$ \\
\hline Residual & 5.807 & 59 & .098 & & \\
\hline Total & 28.106 & 61 & & & \\
\hline
\end{tabular}

a. Predictors: (Constant), Communication Technology, Information Technology

b. Dependent Variable: Marketing Performance

Source: Data Processing Results, 2018

Based on the table above, it can be seen that F-count 113,287 and then the significance value (sig. 0,000 ) when compared between significance values (sig) and alpha value $(\alpha=0.05)$, then the significance value is smaller than alpha value, meaning variable Information Technology and Communication Technology on Marketing Performance has a significant effect. Based on the information stated above, where F-count is 113,287 and free degree (nk-1) or 62-2-1 = 59, the F-table is 3,153 while F-count is 113,287 , so F-count> F-table means that H0 is rejected and $\mathrm{Ha}$ is accepted, meaning that there is a significant effect between the variables of Information Technology and Communication Technology on Marketing Performance. 


\section{Coefficient of Determination}

Table 3.

Coefficient of Determination

Model Summary b

\begin{tabular}{|c|c|c|c|c|}
\hline MODEL & $\mathrm{R}$ & R Square & $\begin{array}{c}\text { Adjusted } \\
\text { R Square }\end{array}$ & $\begin{array}{c}\text { Std. Error of the } \\
\text { Estimate }\end{array}$ \\
\hline 1. & $.891^{\mathrm{a}}$ & .793 & .786 & .31372 \\
\hline
\end{tabular}

a. Predictors: (Constant), Communication Technology, Information Technology

b. Dependent Variable: Marketing Performance

Source: Data Processing Results, 2018

Based on the table above, it can be seen that the correlation coefficient value is 0.891 then the coefficient of determination (R2) is obtained value of 0.793 . This means that there is an effect between Information Technology and Communication Technology on Marketing Performance by $79.3 \%$ while the remaining $20.7 \%$ is affected by other variables that did not involve in this research.

\section{CONCLUSION}

Based on the results of research on the effects of information and communication technology adoption on MSMEs in the retail sector marketing performance in Cibaduyut, Bandung City, the following conclusions were obtained:

1. Based on the results of testing the hypothesis, know count> t-table. This means that H0 is rejected and $\mathrm{Ha}$ is accepted, so there is a significant influence between Information Technology on Marketing Performance. Based on the results of the regression analysis, a coefficient value of 0.583 was obtained which means that when there is an increase in Information Technology, it will increase the marketing performance of MSMEs in the retail sector in Cibaduyut Region.

2. Based on the results of testing the hypothesis, know t-count> t-table. This means that $\mathrm{HO}$ is rejected and $\mathrm{Ha}$ is accepted, so there is a significant influence between Communication Technology on Marketing Performance. Based on the results of the regression analysis, the coefficient value of 0.617 is obtained, which means that when there is an increase in Communication Technology, it will improve the marketing performance of MSMEs in the retail sector in Cibaduyut.

3. Based on the results of testing the hypothesis, know t-count> t-table. This means that $\mathrm{HO}$ is rejected and $\mathrm{Ha}$ is accepted, so there is a significant influence between Information and Communication Technology on Marketing Performance. Then it is known that F-count 113,287 and significance value (sig. 0,000) so that when compared between significance values ( $\operatorname{sig})$ with alpha value $(\alpha=0.05)$, then the significance value is smaller than alpha value, meaning the Information Technology and Technology variables Communication on Marketing Performance has a significant effect on the MSME marketing performance in the retail sector in Cibaduyut.

\section{References}

Abrar, A. N. 2003. Teknologi komunikasi: Perspektif ilmu komunikasi. Yogyakarta: LESFI.

Akpan, O. P. 2007. Information and communication technology in development: Contextuality and promise. Proceedings of the 9th International Conference of Social Implication of Computers in Developing Countries, São Paulo, Brazil. October 24, 2017. https://pdfs.semanticscholar.org.

Apulu, I., Latham, A., \& Moreton, R. 2011. Factors affecting the effective utilisation and adoption of sophisticated ICT solutions: Case studies of SMEs in Lagos, Nigeria. Journal of Systems and Information Technology.

Bhagwat, R., \& Sharma, M. K. 2007. An integrated BSC-AHP approach for supply chain management evaluation, Measuring Business Excellence. 
Collins, J., Worthington, W., Reyes, P., \& Romero M. 2010. Knowledge management, supply chain technologies, and firm performance. Management Research Review.

Ferdinand, A.T. 2000. Manajemen pemasaran : Sebuah pendekatan stratejik. Semarang: Badan Penerbit Universitas Diponegoro.

Haag, S., \& Keen, P. 1996. Information technology: Tomorrow's advantage today. Hammond: Mcgraw - Hill College.

Homburg, C., Grozdanovic, M., \& Klarmann, M. 2007. Responsiveness to customers and competitors: The role of affective and cognitive organizational systems. Journal of Marketing.

Kadir, A., \& Triwahyuni, T. C. H. 2003. Pengenalan sistem informasi. Yogyakarta: ANDI.

Knoll, W.H.C., \& Stroeken, J.H.M. 2001. The diffusion and adoption of information technology in small and medium sized enterprises through IT scenarios. Technology Analysis \& Strategic Management.

Prasetya, D. I. 2002. Lingkungan eksternal, faktor internal, dan orientasi pasar, pengaruhnya terhadap kinerja pemasaran, Jurnal Sains Pemasaran Indonesia.

Ramsey, E., P. Ibbotson., J. Bell., \& B. Gray. 2003. E-opportunities of service sector SMEs: An irish cross-border story. Journal Of Small Business And Enterprise Development.

Retriana, B. 2013. Pengaruh pemanfaatan teknologi informasi terhadap kinerja individual pada kantor dinas kependudukan dan pencatatan sipil Kabupaten Wonogiri. Universitas Muhammadiyah Surakarta. http://eprints.ums.ac.id/.

Rogers, E. M. 1986. Communication technology: The new media in society. London: The Free Press.

Roosdhani, M.R., Wibowo, A.P., \& Widiastuti, A. 2012. Analisis tingkat penggunaan teknologi informasi dan komunikasi pada usaha kecil menengah di Kabupaten Jepara. Jurnal Dinamika Ekonomi \& Bisnis.

Shiels, H., McIvor, R., \& O’Reilly, D. 2003. Understanding the implications of ICT adoption: Insights from SMEs. Logistics Information Management.

Sutarman. 2009. Pengantar teknologi informasi. Yogyakarta: Bumi Aksara.

Trimi, S. 2008. Editorial ICT for small and medium enterprises. Service Business.

Turban, E.J.E., \& Volonino, L. 2011. Information technology for management: Improving strategic and operational peformance, eighth edition. Unitate States of America: John Wiley \& Sons, Inc.

Wahid, F., \& Iswari, L. 2007. Adopsi teknologi informasi oleh usaha kecil dan menengah di Indonesia. Seminar Nasional Aplikasi Teknologi Informasi, Yogyakarta: (SNATI), https://media.neliti.com. 